\title{
A RESEARCH REVIEW ON 50 YEARS AFTER THE BIAFRAN WAR
}

\author{
Ignatius Nnaemeka Onwuatuegwu PhD \\ Philosophy Department \\ Faculty of Arts \\ Nnamdi Azikiwe University Awka
}

\begin{abstract}
Nigeria like every other country has embarked on the journey for nation-building, following the attainment of her independence on the $1^{\text {st }}$ October 1960; however, the nation has stumbled and have faced great obstacles in her journey towards nation-building, most of these obstacles have continued to resurface 59 years after the attainment of independence in Nigeria. The wake of independence no doubt beamed a light of hope, and lots of aspiration for the Nigerian people, however, these hope and aspirations were soon short-lived by the events that followed the early years of independence. As a nation whose strength lies in the unity of her diversity, and as a people whose glory lies in their unique peculiarities and cultural aspirations, it was therefore anticipated that the attainment of independence in Nigeria would to a large extent foster unity among and between tribes and religions, as well as promote the feeling of belongingness, and the creation of a society where every Nigerian is an important stakeholder in the unity and development of the country, not just in spoken or written words, but in action and practice. This paper, therefore, examined the events that led to the onset of the civil war and how these events have continued to shape the nature of politics and inter-ethnic relations in Nigeria after over 50 years.
\end{abstract}

Keywords: Biafra, Nigeria, Civil War, 50 Years.

\section{INTRODUCTION}

Air, Water and Food have been voraciously paraded to be very vital to human survival, in the same manner, is peace, justices, inclusiveness, equality and all other indicators of good governance to the survival and sustainable development of a nation. No nation can make any meaning progress in the face of war, injustices and inequality in the distribution of the gains of democracy across people, regions, tribes, and the many ethnicities that form the nation. The attainment of a functional and egalitarian society is a function of values and ideologies held about the need to pursue good governance from the top government to the grass root. This notion becomes essential because good governance is principally one of the basic requirements for the attainment of sustainable development in all spheres of the society which is a basic requirement for national development (Ernst \& Young, 2014). Nigeria like every other country has embarked on the journey for nation-building, following the attainment of her independence on the $1^{\text {st }}$ October 1960; however, the nation has stumbled and have faced great obstacles in her journey towards nation-building, most of these obstacles have continued to resurface 59 years after the attainment of independence in Nigeria.

The wake of independence no doubt beamed a light of hope, and lots of aspiration for the Nigerian people, however, these hope and aspirations were soon shortlived by the events that followed the early years of independence. As a nation whose strength lies in the unity of her diversity, and as a people whose glory lies in their unique peculiarities and cultural aspirations, it was therefore anticipated that the attainment of independence in Nigeria would to a large extent foster unity among and between tribes and religions, as well as promote the feeling of belongingness, and the creation of a society where every Nigerian is an important stakeholder in the unity and development of the country, not just in spoken or written words, but in action and practice. This was the dream of the Nigerian people! And the post-independence aspirations of the Nigerian people. Sadly, this has remained a dream that is yet to come through for over 50 years following the independence of Nigeria.

Injustice, corruption, exclusion and marginalization, leadership failure, political and religion engineered inter-ethnic crisis and killings, in a state gives way for unrest, protest, hostility and worst-case scenario civil war. This was the events that ushered in inter-ethnic in Nigeria, which later escalated to the onset of pogrom perpetrated by the people of the Northern region of 
Nigerian against the people of the South Eastern region of Nigeria and the eventual breakout of the Biafran war. Although, a plethora of factors are reported to fuel the onset of the Nigerian civil war of 1967-1970, however; the state of corruption, marginalization and perceived injustice in the postindependent Nigeria cannot be completely detached as a motivation for the Nigerian civil war (Aremu, \& Buhari, 2017). The Nigerian civil war of 1966, marked a very down point in the history of Nigeria as a sovereign entity, and its impact remains with Nigeria after over 50 years (Aremu, 2017; Onumonu, 2017).

Although, the war came to an end following the unconditional surrender of the Biafran soldiers; over the years there have been threats of war emanating from different parts of Nigeria, especially the eastern part of Nigeria due to the feelings of perceived marginalization. Today, they have aggressive agitations for self-determination by groups like Movement for the Sovereign State of Biafra (MASSOB), headed by Chief Ralph Uwazuruike and later the Indigenous people of Biafra (IPOB) headed by Nnamdi Kanu. The basis for agitation by these group is based on the development of the Eastern region, the perceived exclusion of the Igbo people from key political positions in the country such as the presidency, as well as the perceived marginalization of the people of the Eastern region. These were the same issues that caused the region to decide to opt-out of Nigeria in 1966. Accordingly, Maiangwa (2016) noted that the spike in agitation for self-determination by groups in the eastern part of Nigeria such as IPOB are by-products of trauma and grievances held by the Igbo people of Nigeria, as a result of perceived or actual repression and marginalization birthed by the memories of Nigerian-Biafra War. Mehmed (2015), added that the grievances held by the Igbo people of Nigeria are also aggravated by memories of the actions of the Nigerian government during the war and as well after the official ending of the war. Most particularly, it is a post-war policy which has been widely criticized for being against the Igbo people by the MASSOB and IPOB separationist group.

Going further, Mehmed (2015), Maiangwa (2016), respectively, have argued that the increase in agitation for self-determination from the Igbo people of Nigeria is a proof that the memories of the mass destruction wrought against the Igbo people during the NigeriaBiafra war are a reality which remains fresh in the heart of many strata of the Igbo community, these grievances according to Volkan, (2013) is sustained due to "transgenerational transmission of trauma." (Volkan, 2013). This paper argues that despite the unconditional surrender of the Biafran soldiers in 1970 that the war has not ended in earnest, as the National question is yet to be sustainably addressed. This paper will, therefore, attempt to probe into and explore the events that lead to the Nigerian civil war, how these factors have continued to resurface. This paper also seeks to examine how the grievances and trauma from Nigeria-Biafran have continued to shape the nature of politics, access and distribution of common resources, inter-ethnic relations and co-existence in Nigeria. To achieve the broad objective of this study, the study, therefore, pose this question; 50 years after the Biafran War: Has the War Ended?

\section{CIVIL WAR: A CONCEPTUAL APPROACH}

Conceptually, war is characterized by the absence of peace in a given geographical location, brought by a physical display of force as well as the aggressive use of force between warring parties, thus leading to the mass destruction of life and properties. Civil war, on the other hand, is construed to imply to the onset of "a politically organized, large-scale, sustained, physically violent conflict that occurs within a country principally among large/numerically important groups of its inhabitants or citizens over the monopoly of physical force within the country" (Gersovitz \& Kriger, 2013).

Similarly, Cockayne et al., (2010) citing the UN Security Council, established that the notion of civil war is characterized by the presence of one or more instantaneous disagreements over generally irreconcilable positions which may directly(1) involve the government of a state, or territory in a state;(2) accommodates the use of armed force, as well as leading to a battle-related death toll rate of over 500 people within a given year in the presence of the conflict; (3) encompass two or several parties, of which the main parties at war are singular or much non-state opposition organization and the government of the state where armed force is employed( UN Security Council cited in Cockayne et al., 2010).

\section{HISTORICAL ANTECEDENT OF SEPARATIONIST AGITATIONS IN NIGERIA}

Since the inception of independence, the task of sustaining unity and ensuring that the nation Nigeria remains as one indivisible sovereign entity has been a very tough one. Due to the continued hatred among ethnic groups, politics of ethnocentrism, as well as perceived marginalization of some ethnic groups the unity of the nation, have been highly threatened with 
International Journal of Engineering Applied Sciences and Technology, 2020

Vol. 5, Issue 1, ISSN No. 2455-2143, Pages 570-578

Published Online May 2020 in IJEAST (http://www.ijeast.com)

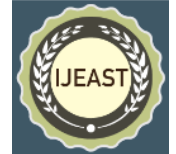

one or more ethnic group threatening to opt-out if their demands are not met. Accordingly, Ameru (2017) noted that prior to the attainment of independence and the years following the attainment of independence in Nigeria, there had been at least five threats of secession from different ethnic groups that comprised the entity called Nigeria. The First secession threat was seen in 1950, following the All Nigeria Constitutional Conference held at Ibadan, the results of the conference, however; were not welcomed by all delegates and as such the delegates from the Northern part of the country in expressing their disagreement issued a threat to opt-out of the federation if their demands are not met. This demands of the northern delegates include allowing the North to lay claims of 136 seats in the proposed House of Representatives on the basis that the population of Northern Nigeria was almost half the population of the entire country. The Northern delegates also demanded the adoption of per capita basis in the allocation of revenue accrued from taxation, anything less than these, the North will opt out of the federation, despite the strong opposition to these demands put up by the delegates from the West and Eastern region, the northern delegates still had their wish done (Awofeso, 2017). There were also accounts of secession threats from the Western region of the federation in that same 1950, which was based on the demands of the Westerners for Lagos not to be separated from the Western region (Aremu, 2017).

Three years after the first secessionist threat was issued by the northern delegate. In 1953, there was a motion by Anthony Enahoro, a member of the Action Group for the Self-determination of Nigeria as a Sovereign entity. This motion has aggressively opposed by the majority Northern representative, thus, leading to its subsequent defeat. In reaction to this the members of the House of Representatives from eastern and western extraction took to the streets to protest as a way of expressing their dissatisfaction of the attitude of the members of the House of Representatives from the Northern extraction, the protest and other events that followed it greatly angered the Northern Legislators to the point that immediately they made their journey back to the North, they issued their second threat to opt-out of the federation (Ojo, 2004).

Just barely six years after the North issued their second threat to secede from the federation, came another secession threat from the North, making it the third one in 10 years. 1959, secession threat by northern Nigeria was championed by no other than Ahmadu Bello, as a resistance to the anticipated coalition government between the National Council of Nigeria and
Cameroons (NCNC) and the Action Group (AG) in the 1959 general election.

Just three years after independence, there was another secession threat this time from the Eastern part of the country and was championed by Dr Micheal Opara. The threat came as a sign of total rejection of the results from the National Population Census of 1963, which according to Dr Micheal Opara as quoted in the West African Pilot, (1964) and cited in Ojo (2004) is "worse than useless". The result of the census claimed that the population of the north was 31million, a number which was higher than the entire population of most African countries as at that time, hence, Dr Micheal Opara requested for the rejection of the results from the North, as the refusal to do so would amount to the Eastern region opting out from Nigeria. However, despite this opposition, the results of the 1963 national population census were later approved and adopted.

Just three years after the secession threat from the Eastern region, came another from the Ijaw speaking tribe of the then Eastern region. This was due to the perceived or real marginalization, neglect of the oilproducing communities in the now Niger Delta region. Moreover, as well as the continued gross underdevelopment racking the region (Aramu, 2012). In reaction to these unpalatable scenes in the region, Adaka Boro through his Niger Delta Volunteer Service (NDVS), a reservists group comprised of estimated 150 young-educated Ijaw youths, announced the secession of the Ijaw-speaking areas of the former Eastern region from Nigeria, which according to Boro would be known and called the 'Niger Delta Republic' on the $23^{\text {rd }}$ day of February in the year 1966. Notably, the Niger Delta Republic only had a life span of fewer than 14 days, following their defeat by the Nigeria military forces under the military reign of late general Aguiyi Ironsi (Muzan, 2014).

Despite the several secession threats from the major ethnic groups in the country due to a perceived deprivation of the regions, Nigeria remained as one nation, although with a shaky foundation. The issues relating to the distribution of the national resources across regions, and series of other issues surrounding the seat of power such as the events surrounding the emergence Gowon as the military head of state, a development which by all standard was abhorred by Lt. Colonel Odumegwu Ojukwu, the then head of the Eastern region, in addition to other unresolved issues even those dated back to prior the onset of independence, hence on the $30^{\text {th }}$ day of May 1967, Lt. Colonel Odumegwu Ojukwu announced the secession 
of the Eastern region from Nigeria and declared the independence of the new country, which he called the Republic of Biafra' (Kirk-Greene, 1971). This development did not sit well with the Gowon Government. Thus, 36 days following the creation of the Republic of Biafra, the then Nigerian government under the Leadership of General Yakubu Gowon declared war on the 'Republic of Biafra' on 6 July 1967 , as a way of forcing the Eastern region back into Nigeria.

\section{Motivations for the Nigerian-Biafran War}

The events leading up to the onset of the NigerianBiafran Civil war are multiple, and they include the following;

\section{The January 15,1966 Military coup}

The event that took place on the $15^{\text {th }}$ of January, 1966 marked a turning point in the history of governance in Nigeria. On the date as mentioned above, the organ of governance in Nigeria made a dramatic transition from civilian to military rule following a successful coup d'état, plotted and executed by five major generals in the then Nigerian army chaired by Major C.K. Nzeogwu. This coup dethrones the government of Abubakar Tafawa Balewa, who was the prime minister of the federation and ushered the military government of Major General Aguiyi Ironsi (Mainasara, 1982), the coup executers based their action of acclaimed nepotism, corruption, inept leadership, and ethnicity among the Balewa's government. The coup saw the death of many prominent politicians and high ranking military officers with some regions having more mortality rate than others.

The Northern and Western region had a fuller basket of mortality, as compared to the Eastern region which lad an empty basket of mortality resulting from the coup. From the Northern region, the death list included Ahmadu Bello, Brigadier Zak Maimalari, Alhaji Tafawa Balewa, Alhaji and Lt. Col. Abogo Largema, from the Western region the mortality list included Chief S.L. Akintola, Brigadier Samuel Ademulegun and Col. Shodeinde. From the Mid-West Region and the Eastern region, the coup saw the deaths of Chief Festus Okotie-Eboh and Lt. Col Unegbe, respectively (Akinseye-George, 2002; Elaigwu, 2005; Achebe, 2012). The disparity in mortality rate from the coup across regions without delay sparked off a mistrust among the regions and suspicion on the actual intent of the coup. Hence, in no due time, the coup was casually branded an Igbo coup and a desperate move from the Igbos to seize power, thus, fueling the growth of hatred from Northerners to the Easterners. This already created inter-region hatred continued to grow but saw a spike when the then military head of government abolished the federalism system of government and enthroned a unitary system of government. The Aguyi Ironsi lead military government also pushed ahead to create a unified National Public Service, while abolishing the formal structure through Decree No 34 of 24 May 1966 (Elaigwu, 2005; Ikime, 2002; Achebe, 2012).

These changes in governance structure introduced by the Aguiyi Ironsi lead military government did not seat well with the North. It went further to revalidate their earlier conceived doubts and suspension on the actual intent of the coup that brought in the military government of Aguiyi Ironsi. Due to fear of perceived tendency for the marginalization of the North in the public service, the North became more aggressive and put up a strong resistance against the decree. In addition to the grievances of the death ratios from the January $15^{\text {th }}$ coup and hunger for retaliation among the Northern leaders, the resistance of the North against the decree kept growing, while the hatred for the Igbos kept piling up, and soon metamorphosed into first antiIgbo sentiments in the North and later to violent demonstrations, riots and the eventual massacre of the Igbos residing in the North (Elaigwu, 2005; Ihunna, 2002; Abubakar, 2002; Ikime, 2002; Achebe, 2012).

The 29 July 1966 Counter-Coup and the Subsequent Massacre of the Igbos in the North The second military coup, stylishly named the 1966 counter-coup, was fueled by the unquenched thirst of revenge for the January 15 coup as well as the changes introduced by the Ironsi government through Decree 34. Prior to July, $29^{\text {th }}$, the elite from the Northern region approached the Ironsi military government with three key demands; firstly, that the Decree 34 should be revoked; secondly, that the plotters of the January $15^{\text {th }}$ coup be punished and thirdly, for the government to suspend efforts towards investigating the event of May 1966, which saw the massacres of the Igbos residing in the North (Achebe, 2012). The countercoup of July 29 1966, and other events that followed it was born out of the inability of the Aguiyi Ironsi lead the military government to yield to the demands of the North. The counter-coup by all standard is nothing but retaliation and vengeance against the Igbos from the North. The coup saw the gross assassination of Adekunle Fajuyi of Western extraction, Aguiyi Ironsi, and many other senior military officers of Eastern extraction (Achebe, 2012; Ikime, 2002). The constant slaughter of the Igbos by the northern became so rampant that civilian and innocent women, children, men of Igbo extraction residing in the North became 
the feasting ground for the bloodthirsty Northerners. Statistically, more than thirty thousand innocent civilian men, women and children of Igbo extraction residing the north were killed, While over hundreds of thousands many others sustained injuries, some were subjected to arson while others saw their life long struggles been looted away, the crime of been Igbo (Abubakar, 2002; Achebe, 2012).

The knowledge of the pogrom committed against the Igbo people became widespread both locally and international; despite the widespread concern both locally and internationally generated by the random killings of the Igbos by the northern, there was notably clumsiness on the part of the Gowon lead military government to still the tide, and curb the unjustifiable and inhumane slaughtering of the Igbo people by the Northerners. This perceived incompetence on the part of the government forced the elites of the Igbo region to conclude that the killings were not just a mere incidence but rather is a well thought out plan targeted at exterminating the Igbo ethnic group (Achebe, 2012). Hence, as a survival instinct, large numbers of Igbos who were yet to be killed in the North, made their way back to the East in order to spare their lives.

\section{The non-implementation of the Aburi Accord Agreement}

The killing of Aguiyi Ironsi and the ascension of Lt. Colonel Yakubu Gowon as the new military head of state did not seat well with some high ranking officers within the Nigerian Army, as it contravenes with impunity the already created leadership structures within the Nigerian Armed Forces. (Onumonu \& Anutanwa, 2017). Specifically, Lt. Col. Emeka Odumegwu-Ojukwu, the then head of Eastern region, overtly showed his displeasure towards the accession of Gowon, as the new military head of state, because he was superior to Gowon within the military hierarchy, they were also several batches of officers who were seniors to Gowon, thus making him the least unqualified to mount the seat of the head of the states. As a result of the above-listed sentiments held by Lt. Col. Emeka Odumegwu-Ojukwu, he vehemently refused to acknowledge the headship of Lt. Colonel Yakubu Gowon (Umoru-Onuka, 2002; Elaigwu, 2005; Ikime, 2002).

Lt. Col. Emeka Odumegwu-Ojukwu, on showing his disapproval of the headship of Lt. Colonel Gowon, absents himself from the Supreme Military Council (SMC) meetings (Ikime 2002). This generated concerns, and thus, after much wheedling on the part of Lt. Col. Emeka Odumegwu-Ojukwu, he reversed his decision to make himself available at the Supreme Military Council meetings, however, he did not lose sight of his security, which according to him is endangered in any region of the country outside the Eastern region. Hence, his conditions for participation in any Supreme Military Council meetings included the conduction of the meeting outside the Nigerian soil or within the territory of the Eastern Region (Ojukwu, 1969).

It was based on these demands from Ojukwu that the famous Aburi Accord meeting came to be, following the intervention of the then Ghanian Head of State, General J.A. Ankrah, who on December 1966, extended his willingness to host a meeting to reconcile Lt. Colonel Odumegwu Ojukwu and Lt. Colonel Yakubu Gowon, in Aburi, in the capital of Ghana, Accra. The meeting was 4 and 5 January 1967, with the host (General J.A. Ankrah) serving as the mediator between Lt. Colonel Odumegwu Ojukwu and Lt. Colonel Yakubu Gowon. The meeting was graced by military leaders of Nigeria Extraction as well as senior police officials (Madiebo, 1980; Forsyth, 2001; Uwechue, 2004; Ojukwu, 1969). The meeting ended peacefully, and both parties were able to reach an agreement, which was signed following the end of the meeting. The content of the Aburi-Accord included the following;

The army should be governed by the
Supreme Military Council (SMC)
under the Chairman of the Head of
the Federal Military Government
and Commander-in-Chief of the
Armed Forces; establishment of a
military headquarters in which each
region was to be represented which
would be headed by the Chief of
Staff; establishment of an Area
Command in each region under an
Area Commander; the SMC was to
deal with all matters of appointment
and promotions of people in
executive posts in the Armed Forces
and the Police and; Military
Governors were to have control
over Area commands in their
regions for the purpose of internal
security (Elaigwu, 2005; Oluleye,
1985; Aremu, 2014).

On return to Nigeria, the Federal Military government made a U-turn departure from the contents of the Aburi-Accord, on the basis that the provisions of the Aburi-Accord were in favour of Lt. Colonel Odumegwu Ojukwu. Hence, its implementation implies a victory for Lt. Colonel Odumegwu Ojukwu. Hence, the right between the Gowon led the military 
head of state and Lt. Colonel Odumegwu Ojukwu, continued as Ojukwu maintained his stance on the Aburi-Accord (Aremu, 2014).

\section{The Creation of 12 New States on 27 May, 1967}

In what could be described as a desperate move by the military government of Lt. Col. Yakubu Gowon, to clap the wings of Lt. Col. Odumegwu Ojukwu, the military head of state in the person of Lt. Col. Yakubu Gowon, declared the creation of twelve new states on the $27^{\text {th }}$ day of May 1967, this led to the dissolution of the regional political structure which the Nation was patterned into. Of the twelve states created, the Eastern region was balkanized into three states, two states for the Western region, one for the Mid-Western Region, which was then called the -Western states, while the remaining six states went into the Northern region (Elaigwu, 2005). The dissolution of the regional political structure was the last straw Lt. Col. Odumegwu Ojukwu, the Governor of the defunct Eastern Region. He decried the illegitimacy of the creation of the new states by the Gowon led military government and thus; refused to acknowledge the existence of the new development.

The creation of twelve new states by the Gowon led military government was perceived by Lt. Col. Odumegwu Ojukwu, as a well-articulated plot against the Igbo people of the Eastern Nigeria, as well as a tactical declaration of war against the Igbo, his assumptions were informed by the fact that the newly created Igbo State (East Central State) was landlocked (Aremu, 2017). As a proactive measure, the Eastern Region Consultative Assembly convened on the $27^{\text {th }}$ May 1967. After much deliberations the Assembly reached an agreement for Lt. Col. Odumegwu Ojukwu summoned "to declare at the earliest practicable date, Eastern Nigeria a free, sovereign and independent state by the name and title of the Republic of Biafra" (Achebe, 2012).

Hence, on the $30^{\text {th }}$ day, in the same month of May 1967, Lt. Col. Odumegwu Ojukwu declared that the Eastern Region is no longer a part of Nigeria, as it is now a sovereign entity which is called the "Republic of Biafra". The announcement of the secession of the Eastern region from Nigeria did not seat well with the incumbent military head of state who saw the act to be unconstitutional. Hence, on the $6^{\text {th }}$ day of July 1967 , the Gowon led Nigerian Military government declared war on Biafra. The war lasted for thirty months and has remained a dark point in the history of human civilization in Nigeria and Africa (Akresh et al., 2012; Okafor, 2014). The war eventually came to an end following the unconditional surrender of the Biafran soldiers on the $15^{\text {th }}$ day, in January 1970 , leaving a death toll of over 2,000,000 (Onuoha, 2016; Banerjee, 2016).

50 Years after the War: Has the War Ended? Indeed, January $15^{\text {th }}, 1970$, brought an end to the thirty months war, on the grounds of "no Victor no Vanquished", as declared by the then military head of state Lt. Col. Yakubu Gowon. However, in reality, the question bordering on if the war has ended cannot be answered in the affirmative with complete sincerity. Though it has been over 50 years, yet the national question is yet to answer, the nation Nigeria is yet to get her balance in terms of fair access to common resources, equal rights and recognition of people from all regions in the nation. The current spike in interethnic hatred among major ethnic groups in Nigeria, and the similar reoccurrences of the events that characterized the period before the war may prompt one to doubt that the war has ended in earnest.

This paper, therefore, argues that January $15^{\text {th }}, 1970$ marked the official end of the Civil war, and also pave the way for the onset of the cold war between the North and the East which has thrived for over 50 years, and will continue if sustainable and strategic efforts are not made from the government at both local and international level, to wade into the crisis, social injustice, ethnic oriented oppression and wide outcry of marginalization of some major and minority ethnic groups in the country. The peace of Nigeria as a nation has embarked on a journey of no return, and the foundations of the Country is greatly shaken by insurgency which was borne from a prolonged marginalization and repression of the Nigerian citizens by the political class. In virtually all regions of the country, there have been a massive outcry of marginalization and neglect on the part of the government. Starting from the Niger Delta regions, as the oil base of the Nation, contribute a greater proportion of the Nigeria gross domestic product. Conversely, a region so rich in oil is lavishing in poverty, with most of its communities becoming inhabitable due to the unregulated activities of the oil companies operating in this region. The continued neglect of the Niger Delta region were the main reasons surrounding the emergence of violent insurgent groups as the Niger Delta Militants, the Niger Delta Avengers, among others (Gidhe, 2017; Makpor, 2017).

There have been a resurface of separationist calls from groups in the Eastern region starting from the Movement for the Sovereign State of Biafra (MASSOB), headed by Chief Ralph Uwazuruike and 
later the Indigenous People of Biafra (IPOB) headed by Nnamdi Kanu. These groups especially, the Indigenous people of Biafra (IPOB) have staged several nationwide protests which in some cases have led to a clash between the protesters and the Nigerian armed forces. Specifically, on the clash between the protesting group (IPOB) reached its climax in February 2016, in a video making the rounds, the Nigerian security forces were seen shooting sporadically at unarmed protesters who were mainly members of the Indigenous People of Biafra, the shooting spree by the Nigerian armed forces led to the death of thirteen protestants and several others wounded (Vanguard, 2016).

There have also been reports of other forms of human right violation against the members of the group mentioned above, which has generated concerns globally. The clash between the members of the indigenous people of Biafra and the Nigerian armed forces escalated to the point that the federal government under the leadership of Muhammadu Buhari in September, 2017 declared the group a terrorist group, while the leader of the group and other apprehended members were charged with treason and other crimes against the Nigerian state.

The manner at which the FGN managed the agitations of the members of the IPOB has further revoked the memories of the events that led to the Civil war and has gone a long way to rejuvenate the feelings of not being treated as an equal stakeholder in the country in many people from the Igbo extraction. This feeling is justified when the treatment melted out on harmless IPOB protesters is compared with the way the FGN is handling the issue involving the Fulani herdsmen's, who carry arms up and down and have been involved in many clashes in which they end up mercilessly killing the unarmed and unsuspecting farmers and villagers. In a study by Nte (2016), it was revealed that the mortality rate from the series of attacks launched by the Fulani herdsmen in different communities in Benue state alone stood at over 5000 deaths, just within the first quarter of 2014 (Nte, 2016). The death statistics go on and on, but surprisingly, the Fulani herdsmen still roam around the country freely and are yet to be proscribed or declared as a terrorist group despite the great harm and havoc they have wrought against the Nigerian people. In terms of infrastructural development not much has been done in the eastern region, accordingly, the Geopolitical Intelligence Service (2017), noted that;

The defeat of Biafra and the murderous revenge the federal troops took in 1970 did not close this dark chapter in Nigerian and African history. Igbos continue to be marginalized. They are underrepresented in nearly all top government positions. The southeast is thoroughly neglected by federal authorities, except in the quasi-confiscation of oil revenues (GIS, 2017)

There have also been evacuation threats from the youths of the northern extraction to the Igbos residing in the north to evacuate their land, on or before the $1^{\text {st }}$ day of October 2017 (Aremu,2017). In reaction to the evacuation threat from the Arewa Youth Group, the Indigenous People of Biafra also issued a counterthreat to Northerners residing in the South East, to vacate the zone at the expiration of the deadline given by the Arewa Youth Group(Sahara Reporters, 2017). All these go a long way to say that there have been a constant war of hatred, thirst for vengeance and acute mistrust in Nigeria, especially between the North and the East.

\section{CONCLUSION}

The quest for nation-building is not a bed of roses, and Nigeria as a nation has had her fair share of the challenges and hurdles built-in in the journey towards building a and egalitarian society. It is, however, important that the fact that no nation can attain unity, peace, stability and sustainable development in the face of corruption, perceived and real marginalization, abuse of human rights, and politics of ethnocentrism be dully registered in the hearts of the Nigerian political class and others within the corridors of power. So long as the national question is yet to be addressed; and the governing compass is yet to be gotten right, the peace of Nigeria as a nation will continue to be distorted by agitations from aggrieved youths, today the agitation for separation from Nigeria is coming from the South Eastern zone, tomorrow it may come from another region of the country.

\section{REFERENCES}

1. Abubakar, D. (2002)., The North and the Nigerian Civil Ware in Osaghae, E.E. et al (eds), The Nigerian Civil War and Its Aftermath, in Osaghae, E.E., Onwudiwe, E. \& Suberu, R.T. (eds.) The Nigerian Civil War and Its Aftermath (Ibadan: John Archers Publishers Ltd).

2. Achebe, Chinua. (2012). There Was A Country. London: Penguin Books Ltd. 
3. Akresh, R., Bhalotra, S., Leone, M., and Osili, U. O. (2012). War and stature: Growing upduring the Nigerian civil war. American Economic Review: papers \& Proceedings. 102 (3), (pp.273-277).

4. Aremu J. O. and Buhari .L.O. (2017) Sense and Senselessness of War: Aggregating the Causes, Gains and Losses of the Nigerian Civil War, 19671970. IAFOR Journal of Arts \& HumanitiesVolume 4 - Special Issue - Winter.

5. Aremu J. O. (2017) Midwifing Nigeria's Fragile Unity: The Role of Obafemi Awolowo in the Nigerian Civil War.European Journal of Social Sciences Studies. Volume 2, Issue 9.

6. Aremu., J.O. (2012), ,Understanding the Role of Ethnic Militia Groups in the Niger Delta Conflict: $1999-2007^{\circ}$, ELA: Journal of African Studies, Nos. 31\&32.

7. Awofeso, O. (2017). Secessionist Movements and the National Question in Nigeria: A Revisit to the Quest for Political Restructuring'. IJRDO-Journal of Social Science and Humanities Research, Volume 2, Issue 7.

8. Banerjee S. (2016) Voices of the Nigerian Civil War: A Study of select poems of Chinua Achebe and Christopher Okigbo. International Journal of English Language Literature and Humanities. Vol. IV, Issue III.

9. Elaigwu, J. I. (2005). Nigeria: yesterday and today for tomorrow. Jos: Aha Publishing House.

10. Ernst and Young, (2014). EY's attractiveness survey Africa; Executing growth, Republic of Zambia, Strategy paper on Industrialization and Job Creation. Lusaka, Zambia.

11. Forsyth, F. (2001). The Biafra story: the making of an African Legend. London: Leo Copper.

12. Geopolitical Intelligence Service (2017) Biafra deserves self determination. Available at https://www.gisreportsonline.com/biafradeserves-self-determination, politics, $2241 . \mathrm{html}$. Accessed $5^{\text {th }}$ May, 2020.

13. Gersovitz, M., and Kriger, N. (2013). What is a civil war? A critical review of its definition and (Econometric) consequences. The World Bank Research Observer, 28(2). Available at https://doi.org/10.1093/wbro/lkt005. Accessed $5^{\text {th }}$ May, 2020.

14. Gidhe I. (2017) Niger- Delta Crisis: Causes and Its Effects on the Socio-Economic Life of the People of Ogoni, River State, Nigeria. International Conference on Social Sciences \& Interdisciplinary Studies.

15. Ihunna, O.I. (2002). The post-civil war Igbo integration question: Between rhetoric and realism. In Osaghae, E.E, Onwudiwe, E. \& Suberu,
R.T. (Eds.), The Nigerian Civil War and its aftermath. Ibadan: John Archers.

16. Ikime, O. (2002). The Nigerian civil war and the national question: A historical analysis. In Osaghae, E. E., Onwudiwe, E. \& Suberu, R. T. (Eds.), The Nigerian civil war and itsaftermath. Ibadan: John Archers.

17. Kirk-Greene, A.H.M. (1971) Crisis_and Conflict in Nigeria: A Documentary Sourcebook 19661969. London: Oxford University Press.

18. Madiebo, A.A. (1980). The Nigerian revolution and the Biafran war. Enugu: Fourth Dimension

19. Maiangwa B. (2016) Revisiting the Nigeria-Biafra War: The Intangibles of Postwar Reconciliation. International Journal on World Peace Vol. XXXIII NO. 4

20. Mainasara, A. M. (1982). The five majors: Why they struck. Zaria: Hudahuda.

21. Makpor, M. (2017). The Niger Delta Avengers: An Assessment of the Causes, Agitation, Major Challenges for OMNCs and Suggestions for Tackling Insurgency in the Niger Delta Region of Nigeria. International Journal of Research in Humanities and Social Studies. 4. ( pp. $16-26$ ).

22. Mehmed, G. (2015) "Forgive and Forget: Reconciliation and Memory in Post-Biafra Nigeria," Dissertation submitted in partial fulfilment of the requirements of the degree MSc in International Development and Humanitarian Emergencies. (p. 15).

23. Muzan, A.O. (2014). Insurgency in Nigeria: Addressing the causes as part of the solution ? AHRLJ Volume 14 No 1 (pp. 217 - 243).

24. Nte, T.U. (2016). Fulani Herdsmen and Communal Conflicts: Climate Change as Precipitator, Journal of Political Science and Leadership Research, vol. 2, no. 1, pp. 26-34.

25. Ojo, E.O. (2004) Secession threat: A Potent Weapon in Nigerian Political Bargaining, 19501964․ Obitun: Journal of the Humanities, Vol. 3, No. 4.

26. Ojukwu, O. (1969). Biafra: selected speeches and random thoughts. New York: Harper \& Row.

27. Okafor, N.W. (2014). Victimization during the Nigerian civil war: A focus on the Asaba Massacre. Unpublished M.Sc. Thesis, Tilburg University.

28. Onumonu, U. P. \& Anutanwa, P. O. (2017). Rethinking the Impact of Nigerian Civil War: Commerce in the Post-Civil War Nnewi and Its Challenges, $1970-2000^{\circ}$.Mgbokoigba Journal of African Studies, Vol. 6, No.2.

29. Onuoha C. (2016) The Nigerian Civil War: A Historical Interpretation.Pyrex Journal of African Studies and Development. Vol 2 (4) (pp.26-34). 
30. Sahara Reporters. (2017). Northern youths declare war on Igbos in the north, ask them to 'leave' within three months. Available at http://saharareporters.com/2017/06/06/northernyouths-declare-war-igbos-north-ask-them$\%$ E2\%80\%98leave \% E2\%80\%99-within-threemonths. Accessed $6^{\text {th }}$ May, 2020.

31. Umoru-Onuka, A.O. (2002). An evaluation of the Nigerian civil war: The case of Kogi Central. In Osaghae, E.E, Onwudiwe, E. \& Suberu, R.T. (Eds,), The Nigerian civil warand its aftermath. Ibadan: John Archers.

32. Uwechue, R. (2004). Reflections on the Nigerian civil war. London: Trafford Publishing

33. Vanguard, (2016) "Will Shooting Unarmed Igbo Protesters Solve the Problem? Vanguard," Available at http://www.vanguardngr.com/2016/03/willshooting-unarmed-igbo-protesters-solve-theproblem/ Accessed 26 March 2016.

34. Volkan V. (2013) "Large-Group-Psychology in Its Own Right: Large-Group Identity and Peacemaking." International Journal of Applied Psychoanalytic Studies Vol 10, no 3 (pp. 210-246).

35. West African Pilot, (1964). 29 February. 